CIRR XXIII (77) 2017, 39-80

ISSN 1848-5782

UDC $321.7(497.5)$

DOI 10.1515/cirr-2017-0002

\title{
The Rise of Direct Democracy in Croatia: Balancing or Challenging Parliamentary Representation?
}

Hrvoje Butković

\section{Abstract}

In 2010 the Croatian Constitution was changed to lower the requirements for the implementation of direct democracy at the national level, in order to save the referendum on Croatia's EU membership from possible failure. Since then, Croatia has witnessed a sharp increase in people's initiatives that have managed to block a number of the government's reform proposals. Therefore, the newly discovered appeal of direct democracy in Croatia has created a new environment for the operation of its representative democracy. Starting from theoretical notions, this paper analyses the practice of direct democracy in selected transitional countries, which could be instructive for Croatia. In its central part, the paper explores the obstacles that stand in the way of the efficient implementation of direct democracy in Croatia.

KEY WORDS:

direct democracy, referendums, initiatives, transitional countries, Croatia 
It is difficult not to acknowledge the potential of direct democracy in terms of empowering citizens, breaking political deadlocks, and further democratizing the political system, despite the frequent criticism levelled against it of being a tool for achieving populist agendas. There have been, however, almost as many experiences with direct democracy as there are democratic countries in the world, which makes the task of transferring best practices from abroad difficult. Furthermore, direct democracy may introduce instability into a political system and could easily be hijacked by interest groups using it as a veto instrument against the implementation of reforms. Therefore, the application of direct democracy in countries with a short democratic history often walks a thin line between being advantageous and disadvantageous for the political system.

The aim of this paper is to analyse how direct democracy has been implemented in Croatia in the period since its independence.' Additionally, the paper examines the reasons behind the growing application of direct democracy in Croatia since 2010 and discusses perspectives on how to use it more efficiently in the future. It argues that direct democracy represents a useful instrument for improving the overall democratic quality of a given political system. However, it also stresses that direct democracy should be limited in such a way that it clearly serves as a supplement to representative democracy and not as a tool for its institutional weakening.

In terms of methodology this paper primarily relies on a qualitative analysis of secondary sources such as academic articles and books. However, it also uses statistics on different referendums and legislative provisions. The method of comparative analysis is also applied with respect to the practice of direct democracy in selected transitional countries. Throughout the article, particular attention is paid to the chronology of events in order to determine the causes and effects of particular developments.

The first draft of this paper was presented and debated at the workshop "Rethinking Representation? The Changing Environment for Parliamentary Democracy", held at the Institute for Advanced Studies in Vienna in March 2015. The event was organised within the project "PADEMIA - Erasmus Academic Network on Parliamentary Democracy in Europe", financially supported by the European Union's Erasmus+ Lifelong Learning Programme. IRMO was a partner institution on the PADEMIA project. 
The paper comprises five sections. Following the introduction, the next section analyses from a theoretical perspective the concept of direct democracy and its relationship to representative democracy. It presents definitions of the most important terms as well as other insights that are important in order to better understand the parts that follow.

The subsequent section examines the practice of direct democracy in Hungary, Lithuania, and Slovenia. These countries were chosen due to the similarities of their socio-economic conditions with those in Croatia and because of their rich and distinctive experiences with the implementation of direct democracy. Out of all new EU member states, direct democracy in Slovenia has the strongest influence on the political system, which is why its experiences are relevant for this paper. The Lithuanian practice is important due to the fact that out of all the new EU member states the country's legal system recognises the amplest variety of the different instruments of direct democracy. Finally, Hungary was chosen because the importance of direct democracy for the country's political system has drastically changed on more than one occasion in the past 25 years.

The main section is reserved for the analysis of direct democracy in Croatia. It shows that for Croatian political elites the strengthening of direct democracy was never a goal in itself. Rather, this development in Croatia merely represented an inevitable technical side-effect of the EU accession process. The section examines the changing conditions for the implementation of the referendums and the initiatives (also known as the people's initiatives), which since 2010 have allowed for the successful challenging of a number of the government's reform proposals. It also critically analyses the provisions of the most recent attempt at changing the national Law on the Referendum, focusing on its advantages and shortcomings. Finally, the concluding section sums up the most important insights and conclusions. 


\section{Direct versus representative democracy}

Direct democracy concerns all constitutional and other regulations through which citizens of one country or a sub-national unit are allowed, through voting independently and directly, to decide on a specific political question or to place it on the agenda (Kost 2008: 10). In other words, direct democracy denotes a variety of processes and institutions that guarantee people's direct involvement in political decision-making (Maduz 2010: 1). For Butler and Renney (1978), from the government's perspective there are three principle reasons for using the instruments of direct democracy: (i) constitutional obligation, (ii) increasing the legitimacy of decision making and (iii) transposing difficult decisions to the people in order to avoid being held accountable for their effects.

Having in mind the situation in Switzerland, Vatter (2000) classifies the different instruments of direct democracy by using a two principle criteria. Firstly, he distinguishes whether these instruments are initiated by a simple government majority or by a minority of representatives or citizens. Secondly, he observes whether they use a simple popular majority as a decision rule or a minority veto (ibid: 175). Reflecting on the Croatian experience with direct democracy, Smerdel (2013: 164-165) distinguishes referendums: i) according to the size of the political community (state or local referendums); ii) according to the matter which is being decided (whether it is a constitutional referendum, legislative referendum, referendum on association or dissociation, or referendum on other issues); iii) according to the legal nature of the referendum question (obligatory or consultative) and iv) according to who initiated it (a referendum following a decision of a state body or a referendum that is a product of the people's initiative).

According to Jung (2001) and Merkel (2014) there are three principle instruments of direct democracy, depending on the initiation criteria (see Figure 1). The first category refers to initiatives which can be launched through obtaining support from the prescribed number of citizens. The initiatives can further be broken down to legal initiatives (initiated from civil society) and referendum initiatives (initiated by those who govern, usually the opposition MPs). Both legal and referendum initiatives fall 
under the category of initiatives, because in each case their initiation depends on the collection of a prescribed number of signatures. The second category is a referendum that can be initiated by the government or the parliament. Thirdly, there is the obligatory referendum, which is launched automatically whenever a decision needs to be made on a prescribed constitutional or some other legal question. The referendums and obligatory referendums can both be sub-divided into decisionmaking referendums and compliance referendums. The basic distinction between initiatives on one side and referendums on the other will be used as the framework for analysis in the rest of this article, due to its applicability to the circumstances in transitional countries.

\section{Figure 1. Instruments of direct democracy}

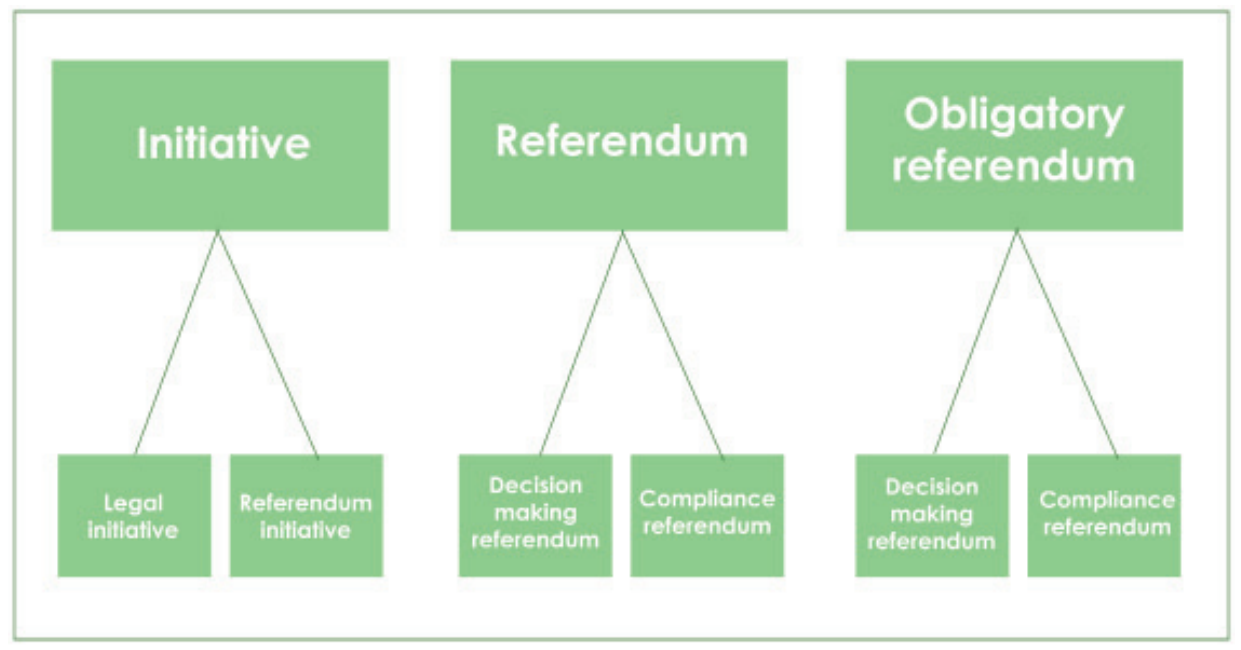

Sources: Jung (2001) and Merkel (2014), slightly modified.

Reflecting on the effects of the referendums and initiatives, Möckli (1994) notes that while the former has a stabilizing effect on the political system, the opposite is usually true with respect to the latter. In his view, initiatives weaken the positions of political parties and strengthen those of interest groups. Furthermore, they have legitimizing effects on the political system (ibid).

As indicated in the definition, direct democracy can be implemented at the national and at the sub-national (local) level, and quantitatively most experiences with direct democracy concern the latter. However, it is not 
easy to compare national and local experiences because, at the local level, the range of issues that can be decided through initiatives or referendums is very limited. Furthermore, in terms of content, exercises in direct democracy at the local level tend to be less important (Schmitt 2014: 65).

Direct democracy represents a political instrument that operates within a larger framework of representative democracy and, as such, it covers just a small part of legislative decision-making (Kost 2008: 12; Merkel 2014: 5). Still, the relationship between direct and representative democracy is not free of controversy due to questions concerning legitimacy. As a rule, referendums attract fewer voters than elections, which raises the question of their legitimacy in a situation where the decision taken through a referendum opposes the view taken by the government or the position of its majority in the parliament (Merkel 2014: 8). ${ }^{2}$

In the given setting the adequate thresholds, in terms of percentage or the number of voters, represents an issue of much significance. This concerns both the minimal number of citizen signatures that need to be collected for the initiation of initiatives as well as the thresholds with respect to the percentage of citizens casting their votes that are required. Concerning the latter, a differentiation can be made between the participation quorum and the acceptance quorum. While the participation quorum prescribes a minimal turnout of voters in order for the initiative or referendum to be considered legal, the acceptance quorum makes the legality of the voting dependent upon the acceptance of a proposal by a certain percentage of voters (Podolnjak 2014: 216). The overall concern with the thresholds is that if they are set too low, there is a legitimacy problem vis-à-vis representative democracy. If, on the other hand, the thresholds are set too high, the flow of innovative bottom-up initiatives could be obstructed (Merkel 2014: 10). The examples that will be analysed in this article will show that participation quorums of $50 \%$ or more should be avoided because they make direct democracy almost impossible.

From the classical authors the strongest advocate for direct democracy was Jean-Jacques Rousseau. In his seminal work The Social Contract

2 Croatian experiences support this claim. For example, in the 2011 parliamentary elections the voter turnout was $66.57 \%$ and in 2015 it was $60.82 \%$ (SECC 2011; SECC 2015). Such solid voter turnout can be contrasted with the much lower turnout in the latest national level referendum/initiative. In 2012 the referendum on EU membership had a turnout of $43.51 \%$, while a 2013 initiative on the constitutional definition of marriage attracted $37.90 \%$ of voters (SECC 2012; CCRC 2013). 
Rousseau prizes a vision of individuals that are directly involved in the creation of the laws that will govern their lives. However, Rousseau's concept of direct democracy is not in compliance with the reality of contemporary states and the modern notion of representative democracy (see Vospernik 2014: 23-25). Among 20th century classical authors opposition to direct democracy was widely shared. Schumpeter (1962) claimed that the average voter lacks the competence and political interest to participate directly in decision-making processes. He also argued that referendums contribute to the polarization of society. An additional claim was that direct democracy leads to policies that could be harmful to minority groups. This argument was often quoted by Sartori (1992) who criticized referendums for their exclusive character. In his opinion referendums leave no space for negotiations and compromises. As such, they represent instruments of majoritarian democracy, which neglect or even endanger minorities.

Contemporary researchers of direct democracy often rightly challenge these classical claims. Referring to the standpoint that the average voter lacks competence, Bowler (2013: 1789) notes that the distinction between representative democracy, on one side, and direct democracy, on the other, is somewhat artificial since most actions within the framework of direct democracy tend to be strongly influenced by MPs. There are studies showing that voters are capable of making reasonable decisions despite all the shortcomings of direct democracy in terms of its effects on efforts to build a consensus and the quality of the deliberations produced throughout campaigns (Lupia and McCubbins 1998). Scholars have presented evidence that as a result of direct democracy political outcomes correspond better with individual preferences (Hug 2004; Frey 1994). Similarly, there are studies showing that more frequent usage of direct democracy causes higher voter turnout, enhances citizen's knowledge of politics (Smith and Tolbert 2004; Kriesi and Wisler 1996), creates a more engaged citizenry (Boehmke and Bowen 2010), and reduces protest behaviour (Fatke and Freitag 2013). Finally, citizens are more likely to be satisfied with how democracy works if there are possibilities for their direct participation in political processes (Bernaver and Vatter 2012). The argument that direct democracy leads to the introduction of policies that could be harmful to minority groups has also been contested. Authors have indicated that, in accordance 
with the recommendations of the Venice Commission, many countries exclude such and other sensitive issues form direct voting by citizens (Podolnjak 2014: 211; Kaučič 2014: 75; Council of Europe 2007: III 3).

Still, direct democracy should not be idealised despite all of its possible contributions to the further democratization of a certain political system. It should be kept in mind that the primary actors in direct democratic campaigns are always political elites, civil society groupings or individuals, and not "the people" as such (Merkel 2014: 14). In Switzerland, the cradle of modern-day direct democracy, initiatives and referendums make a significant contribution to political stability. However, direct democracy in Switzerland is much more organized and linked to procedures of representative democracy than is the case in Central and Eastern Europe and other parts of the world, where direct democracy does not have a long tradition (Maduz 2010: 2). A further problem is that revisions of direct democratic decisions are difficult to achieve. In other words, direct democratic procedures lack a correction mechanism that would be comparable with the right of citizens to vote the government out of office (Merkel 2014: 19). ${ }^{3}$ Last but not least, there are those who claim that an increased use of direct democracy compromises the conditions that facilitate the successful growth of the economy because it bestows interest groups with the power to slow down reform processes (Borner and Rentsch 1997; Merkel 2014: 16).

Direct democracy can strengthen a democratic political system because it can enable the political system to move closer to the democratic ideal. However, in order for citizens' direct voting to be beneficial for democracy it has to be very precisely coordinated with the representative system, which is currently not the case in Croatia and most other Central and Eastern European countries. Furthermore, it is crucial to treat direct democracy as a supplement of representative democracy and to use it for determining only the most important issues.

3 For example, according to the Croatian Law on the Referendum (Art. 8) the decisions reached by means of direct democracy cannot be changed by representative bodies for a year and the voting cannot be repeated for six months. However, the problem lies in the fact that a one-year suspension on a possibility of changing the decision by representative bodies does not apply to referendums on alliances or the dissolution of alliances with other states and to popular initiatives. Concerning referendums on alliances or their dissolution the existing exception is adequate because it is in line with the Croatian Constitution (Art. 142) which indicates that such decisions cannot be changed unilaterally by state bodies. On the other hand, concerning popular initiatives things are not as simple. The inexistence of a one-year suspension poses a dilemma of when a decision reached by means of an initiative could be changed by a representative body. One possible answer is that it may never be changed which could hardly withstand legal scrutiny because that would undermine the power of a parliament to create and change the laws and the constitution. The other answer would be that a decision reached by means of a popular initiative could be changed immediately after its enactment. From a legal perspective this represents a better solution, but it leaves us with the question of what is then the purpose of having such legally binding initiatives in the first place. 


\section{Direct democracy in selected transitional countries}

\section{Hungary}

The Hungarian political system is usually called dualistic because the government and the single chamber parliament do not possess the usual powers over each other. The government has no power to dissolve the parliament, while the parliament has no power to recall individual ministers (Machos 2002). The country has a combined electoral system with a preponderant proportion of majoritarian mandates, which strengthens the position of two big parties (Vospernik 2014: 554). Since the end of socialism the rules for the application of direct democracy in Hungary have been thoroughly changed on several occasion by means of either legislative changes or rulings of the Constitutional Court (ibid: 558).

At the beginning of the transition period the conditions for the implementation of direct democracy were rather favourable. The parliament itself could initiate a people's initiative on almost any question as long as one third of its representatives supported the proposal. The decision reached on the referendum bound the parliament for two years. The only (though important) restrictive element in the implementation of direct democracy was a participation quorum of at least $50 \%$ (Komáromi 2013: 48).

Throughout the 1990s the Constitutional Court, through its rulings, tried to better regulate the implementation of direct democracy. This activity influenced the 1997 constitutional and legislative changes to the Law on the Referendum, which introduced a more precise system (Vospernik 2014). Through this reform the number of signatures by citizens that had to be collected in order to successfully implement initiatives was increased to 200.000 in most cases. The time span for the collection of signatures was limited to four months when the initiative was started by those who govern and two months when citizens initiate it. The list of prohibited issues that cannot be decided by means of direct citizen voting was enlarged. For

example, it was forbidden to hold a referendum or initiative concerning the dissolution of the national and local parliaments, the Law on the 
Referendum, the forming of the government, a declaration of war, military interventions, and amnesty. Additionally, a control system for initiatives was established by means of a validation procedure in the National Election Committee. Finally, and most importantly, the 1997 reform replaced the $50 \%$ participation quorum with a $25 \%$ approval quorum, which resulted in an increased use of direct democracy (Komáromi 2013).

The next significant reform was implemented in 2011 with the clear intention of narrowing the possibility for implementing direct democracy. On that occasion, some forms of initiatives were abolished, such as those that obliged the parliament to discuss problems found to be important by 50.000 citizens. Furthermore, the right of parliamentarians to announce national referendums was restricted, which disrupted the balance of power between the parliament and the government in favour of the latter. Arguably, the most important change concerned the re-introduction of the 50\% participation quorum (László 2016; Pállinger 2014).

The 2011 changes could be viewed in the context of a desire to stabilize the political system, at the expense of further democratic developments. Namely, most initiatives used to be initiated or supported by the opposition with the clear intention of destabilizing the government. Only one initiative (from 2004 concerning double citizenship for Hungarians that do not live in Hungary) has not been initiated by a political party (Vospernik 2014: 577). This development corresponds with the classic observation that leaders of political parties tend to favour direct democracy when in opposition but attempt to limit its scope when in power (Frey 2003). Furthermore, it could be concluded that in Hungary after the politically important referendums on accession to NATO (1997) and the EU (2003) the need for preserving the low participation quorum lost relevance (Vospernik 2014: 567-568).

An additional problem in Hungary is that there are no institutional preconditions for developing a dialogue between representative and direct democracy. In case 200.000 signatures are collected, the parliament has to schedule voting on the initiative. However, it cannot issue a counterproposal, and it does not have to make a statement or debate the initiative (Pállinger 2014). The lack of regulations concerning the financing of referendums and initiatives is also problematic (László 2016). 
Through the referendum on mandatory migrant quotas held in October 2016 the Hungarian government tried to legitimise its own controversial policy towards migrants within the EU. It is, however, questionable whether in circumstances of widespread anti-migrant sentiments the equality between supporters and opponents of the proposal could have been respected, as recommended by the Venice Commission in its Code of Good Practice on Referendums (Council of Europe 2007: I 2). ${ }^{4}$

\section{Lithuania}

The political system of Lithuania represents a unique combination of presidential and parliamentary elements. The president of the republic possesses competences in the domain of foreign policy and has strong influence with respect to choosing the head persons for the numerous governmental bodies. Additionally, the president fulfils an important role in the legislative process; through his/her veto powers, law initiation powers, and the right to demand changes to draft laws (Vospernik 2014: 429). The parliamentary representatives are elected through a combined electoral system with an equal proportion of majoritarian and proportional mandates, but despite this the country has one of the most fragmented party scenes in Europe (Somer 2012: 86). The government is one-sidedly dependent on a single chamber parliament and parliamentarians have massive influence over the government's agenda (Vospernik 2014).

Ever since the country's independence in 1991, the Law on the Referendum has experienced numerous modifications. However, these changes have not led to drastic shifts with respect to the implementation of direct democracy, because the basic parameters have stayed mostly unchanged (Somer 2012). Unlike in some other countries, there are no restrictions on the issues that can be decided by means of direct democracy and a decision reached by the direct voting of citizens cannot be changed in the parliament. Additionally, there are rather favourable conditions for starting an initiative by the opposition MPs. A referendum initiative could be initiated by one fourth of the MPs, and in fact $50 \%$ of all implemented initiatives were initiated

4 Ultimately, this referendum failed because it could not reach the participation quorum of $50 \%$ (National Election Office of Hungary 2016). 
by the opposition.

Still, in Lithuania there are many serious obstacles to the efficient implementation of referendums and initiatives, such as the very high threshold for participation and the short time for the collection of signatures (Vospernik 2012). With respect to national level initiatives, in most cases it is necessary to collect 300.000 citizens' signatures $111.4 \%$ of the electorate) in three months. Furthermore, there is a participation quorum of at least $50 \%$ of voters (ibid: 439 ), which applies to all instruments of direct democracy (see Figures 2 and 3 ).

In 2003 the high participation quorum caused fear among Lithuania's political class that the EU membership referendum might not pass. Therefore, the participation quorum for the referendums that deal with the transfer of sovereignty to international organizations was lowered to $33 \%$. Ultimately, this action proved unnecessary, because $63 \%$ of the total electorate voted in the EU membership referendum and the yes vote took $91 \%$, which is $57 \%$ of the total electorate (Somer 2012: 82).

The Lithuanian legal system altogether recognises nine different instruments of direct democracy, but not all forms have been used in practice (Vospernik 2014: 441). Additionally, the success rate is rather poor, because only five referendums and initiatives reached full implementation (CECRL 2016).

\section{Slovenia}

The Slovenian political system corresponds to Lijphart's (1999) consensus model of democracy. This implies a high number of effective parties (4.99), comparatively low executive dominance (average duration of the government is 1.7 years), pronounced bicameralism, a rigid constitution, and a strong role reserved for the Constitutional Court (Vospernik 2014: 389). The strength of the country's legislative branch is also visible from the fact that the prime minister cannot replace any of his ministers without the parliament's approval. Additionally, neither the president nor the prime minister possesses the power to dissolve the parliament, whose members are elected through a proportional electoral system (ibid: 391). 
The 1991 Slovenian Constitution and the 1994 Law on the Referendum envisaged a strong role for direct democracy. They granted the right of ordering a legislative veto referendum via the initiative of one third of the parliamentarians without any participation quorum. Moreover, until 2012 the participation quorum did not apply to any type of referendum or initiative, with the exception of constitutional referendums initiated by one third of the parliamentarians, where the participation of voters was prescribed at 50\% (Kaučič 2014). Consequently, it must be stressed that the average turnout for referendums and initiatives is $36.27 \%$, which is almost half that of the average turnout for the parliamentary elections (Vospernik 2014: 414). The number of signatures from citizens that need to be collected for an initiative is not set to be excessively high (40.000 in a country of a 2 million). However, the unfavourable elements refer to the time span provided for collection (30-45 days), and the fact that signatures need to be collected in the offices of the local administration (Kaučič 2014).

The generally favourable conditions for the implementation of direct democracy in Slovenia resulted in $76 \%$ of referendums and initiatives being decided in accordance with the wishes of their initiators (Vospernik 2012: 414). In the period between 1990 and 2015, 24 national referendums and initiatives were successfully implemented (see Figures 2 and 3), which is more than in any other transitional country (CECRS 2016). There were 15 successfully implemented initiatives, out of which eight were started by the opposition MPs, underlining the importance of the opposition in the implementation of direct democracy. Therefore, it could be concluded that direct democracy in Slovenia creates a second centre of power that oscillates around the opposition (Vospernik 2014: 419). According to Vospernik (2014: 411), the 2003 NATO and EU accession referendums were among the few that obtained broad support from almost all political parties and succeeded in obtaining high voter turnouts (NATO 60.43\%, EU 60.44\%).

In 2012 Slovenia initiated constitutional changes aimed at re-regulating the implementation of direct democracy. Changes were introduced aimed at somewhat restricting its implementation. Accordingly, the right of one third of the parliamentarians (30 MPs) and of the second house of the Slovenian Parliament to start initiatives vetoing legislative 
proposals was abolished (Kaučič 2014: 70). This action was said to be necessary for the coherent application of the principle that only voters should be granted the right to demand direct voting, since they do not directly participate in the legislative process (Podolnjak 2015). For Igor Kaučič this was a welcome move because it limited the possibility of using direct democracy for settling differences between political parties or political differences between the two houses of the Slovenian Parliament (2014: 73).

Legislative referendums and initiatives became conditioned on the participation of at least $20 \%$ of voters. More precisely, a quorum of rejection was introduced according to which a law would be rejected through the referendum if at least $20 \%$ of citizens voted against it (Podolnjak 2015). Last but not least, certain issues were excluded from being decided through direct democracy, such as laws concerning: urgent matters to ensure the defence of the state, consequences of national disasters, taxes, custom duties and other compulsory charges, state budgets, ratification of treaties, as well as the elimination of unconstitutionality in the area of human rights (Kaučič 2014). However, it must be underlined that all financial and budget laws were not excluded from direct voting but only those precisely listed, which are considered to be crucial for the financial stability of the country (ibid).

The implemented constitutional changes did not have drastic effects on the practice of direct democracy in Slovenia, because, in comparison to other countries, the conditions were still rather favourable. However, the adopted higher level of precision is expected to limit the influence of the Constitutional Court, which in the past had frequently intervened in matters concerning direct democracy, claiming that unconstitutional consequences might result (Ribičič 2014: 64). 
Figure 2. Number of fully implemented national level referendums and initiatives $1990-2015^{5}$

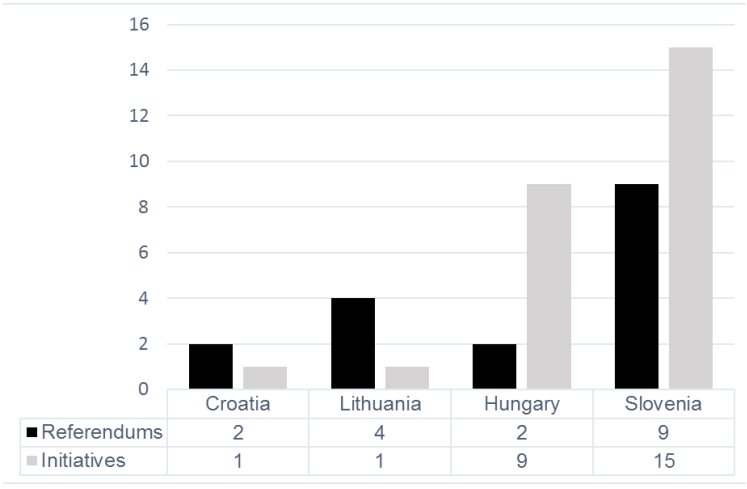

Sources:

1. SECC - State Electoral Commission of the Republic of Croatia, 2016. Elections/Referendums Archives in Chronological Order, [online] Available at: http://www.izbori.hr/ws/index.html? documentld=A758299 505B80F02C1257C8400606C3B [accessed I December 2016].

2. CECRL - Central Electoral Commission of the Republic of Lithuania, 2016. Previous Referendums, [online] Available at: http://www.vrk.lt/en/ankstesni [accessed 1 December 2016].

3. National Election Office of Hungary, 2016. National Referendum, [online] Available at: http://valasztas. hu/en/ref2016/index.html [accessed 1 December 2016]; Vospernik (2014: 571).

4. CECRS - Central Electoral Commission of the Republic of Slovenia, 2016. Referendums, [online] Available at: http://www.dvk-rs.si/index.php/si/arhiv-referendumi [accessed 1 December 2016].

Figure 3. Number of failed national level referendums and initiatives 1990-2015 due to inability of reaching the prescribed quorums

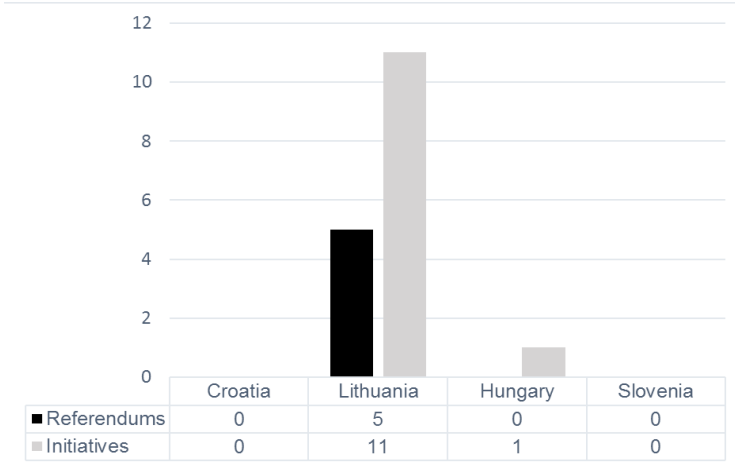

Sources:

1. see Table 3 .

2. CECRL - Central Electoral Commission of the Republic of Lithuania, 2016. Previous Referendums, [online] Available at: http://www.vrk.It/en/ankstesni [accessed 1 December 2016].

3. National Election Office of Hungary, 2016. National Referendum, [online] Available at: http://valasztas. hu/en/ref2016/index.html [accessed 1 December 2016]; Vospernik (2014: 571).

4. CECRS - Central Electoral Commission of the Republic of Slovenia, 2016. Referendums, [online] Available at: http://www.dvk-rs.si/index.php/si/arhiv-referendumi [accessed 1 December 2016].

5 In cases when voting is carried out on several questions, each question is counted as a separate referendum or initiative. 


\section{Croatia's democracy in the age of referendums}

\section{A chronology of the national and local referendums}

Before going into the details of how direct democracy is implemented in Croatia it is important to set it in a wider context by shortly describing the features of Croatia's representative democracy. The Croatian Constitution (Art. 71-72) prescribes a unicameral parliament, which is elected every four years. The Law on the Election of Members of the Croatian Parliament (LEMCP) defines the electoral system as proportional (Art. 40), whereby citizens elect 140 MPs in ten territorial units (Art. 38). Additional MPs are elected in a special constituency for Croatian citizens living abroad as well as a constituency for ethnic minorities within Croatia as a whole (Art. 44 and 45). The changes to the LEMCP imposed in February 2015 introduced the possibility of preferential voting. The candidates that obtained more than $10 \%$ of preferential votes within any particular list are given the advantage over all other candidates regardless of their numerical position on the list (Art. 16 and 38).

According to the Croatian Constitution (Art. 87) the Croatian Parliament can initiate national level referendums concerning constitutional changes, the adoption of new laws, or any other issue in the area of its jurisdiction. Referendums can also be initiated by the president of the republic on the proposal of the government and with the co-signature of the prime minister. However, in such cases, the Constitution limits the thematic scope of a referendum to constitutional changes and issues that are important for the independence, unity, and existence of Croatia. The decisions produced through the referendums are made by a majority of the voters taking part therein and they are obligatory for the government (Croatian Constitution, Art. 87; LoR, Art. 6 and Art. 8). However, the Constitution (Art. 87) and the Law on the Referendum (LOR) in articles 57-59 also prescribe for the possibility of a consultative referendum.

Local level referendums are regulated by the LOR and the Law on the Local and the Regional Self-government (LLRS). According to the LoR (Art. 4) local referendums can be initiated by representative bodies of the 
local and regional self-government on issues that concern their areas of responsibility. According to the LLRS, local referendums can be initiated on the proposal of a mayor, a municipal perfect, a county perfect, one third of the county council members, or one half of the town or municipality council members (LLRS, Art. 24). A proposal for a local referendum needs to be confirmed by the majority of representatives of the local/regional representative body (LLRS, Art. 24). The LoR (Art. 11) prescribes that both national and local referendums need to be implemented in no less than 20 and no more than 40 days since the announcement of this decision.

Until 2010 the development of direct democracy at the national level was halted by very restrictive implementation requirements. Accordingly, both the optional constitutional as well as the legislative referendums required a participation quorum of at least $50 \%$ of all voters registered in the country. The requirements for the implementation of the obligatory constitutional referendum, reserved for association and dissociation, were even stricter, stipulating the acceptance (or refusal) quorum of least $50 \%$ of all registered voters (Grubiša 2012: 55). In such circumstances it is not surprising that throughout its newest history Croatia has implemented just two national referendums and one national initiative: a referendum on the country's independence, a referendum on its EU membership, and an initiative concerning the constitutional definition of marriage (see Tables 1 and 3).

Anticipating a low turnout for the EU referendum, based on public opinion surveys (Širinić 2011), in 2010 the requirements for the implementation of direct democracy at the national level were lowered, in order to save the EU referendum from possibly failing. This was done by means of constitutional changes, supported by all major parties, which abolished the requirements for any specific participation quorum at the national level (Art. 87 and Art. 135). This example proves the old hypothesis that direct democracy may have indirect effects on the political elite by fostering consensus with respect to the decision-making process (Neidhart 1970). Ultimately, as indicated in the previous section, similar developments were registered in Hungary and Lithuania, prior to their accession to the EU.

Subsequently, the Constitutional Law on Implementation of the Constitution of the Republic of Croatia (CLICRC) noted that within a period of six months the LoR should be harmonized with the Constitution (Art. 7). Despite this, 
to this date the LoR has not been changed, which has had paradoxical implications for the implementation of direct democracy in the country. Namely, while at the national level there is no longer a participation quorum, at the local level (see Tables 2 and 4) the participation quorum of $50 \%$ of locally registered voters still holds (LoR, Art. 6).

The results of the EU referendum held on 22 January 2012 showed that the concerns of political elites over the extent of citizens' support for EU membership were justified. In the referendum, 66.3 per cent of citizens voted in favour of accession with a turnout of only 43.5 per cent (see Table 1). Such results were in contrast to the advice offered by the majority of parliamentary political parties and their MPs, which overwhelmingly expressed their unreserved support for EU membership and exhorted citizens to vote for accession (Butković 2015). Clear opposition to EU membership was expressed by only one conservative right-wing party, which at the time had one seat in the parliament (ibid). This confirms that in Croatia, just as elsewhere in the EU, the MPs tend to be more supportive of the Union than the voters (Avel and Raunio 2012: 20).

\section{Table 1. National level referendums}

\begin{tabular}{|l|l|l|l|l|l|}
\hline No. & $\begin{array}{l}\text { TOPIC OF THE } \\
\text { REFERENDUM }\end{array}$ & DATE OF VOTING & $\begin{array}{l}\text { TYPE OF THE } \\
\text { REFERENDUM }\end{array}$ & $\begin{array}{l}\text { TURN } \\
\text { OUT }\end{array}$ & $\begin{array}{l}\text { PERCANTAGES } \\
\text { FOR / AGAINST }\end{array}$ \\
\hline 1. & $\begin{array}{l}\text { Independence } \\
\text { of Croatia }\end{array}$ & 19.05 .1991$. & Obligatory & $83.56 \%$ & $\begin{array}{l}93.24 \% \text { for } \\
4.15 \% \text { against } \\
1.18 \% \text { non-valid }\end{array}$ \\
\hline 2. & EU membership & 22.01 .2012$. & Obligatory & $43.51 \%$ & $\begin{array}{l}66.27 \% \text { for } \\
33.13 \% \text { against } \\
0.60 \% \text { non-valid }\end{array}$ \\
\hline
\end{tabular}

Sources:

1. RCIR - Republic Commission for Implementation of Referendums, 1991. Referendum on the status of Republic of Croatia, [online] 19 May. Available at: http://www.izbori.hr/ws/index.htmle documentld=D F2CA3FEF99BA5CBC1257C5C004BF6B4 [accessed 1February 2017].

2. SECC-State Electoral Commission of the Republic of Croatia, 2012. Referendum on the EU membership, [online] Available at: http://www.izbori.hr/izbori/dip_ws.nsf/public/index? open\&id=9B1A\& [accessed 1 February 2017]. 


\begin{tabular}{|l|l|l|l|l|l|l|}
\hline No. & $\begin{array}{l}\text { TOPIC OF THE } \\
\text { REFERENDUM }\end{array}$ & TOWN & $\begin{array}{l}\text { DATE OF } \\
\text { VOTING }\end{array}$ & $\begin{array}{l}\text { TYPE OF THE } \\
\text { REFERENDUM }\end{array}$ & TURN OUT & $\begin{array}{l}\text { PERCANTAGES } \\
\text { FOR / } \\
\text { AGAINST }\end{array}$ \\
\hline 1. & $\begin{array}{l}\text { Corrections } \\
\text { of the county } \\
\text { borders }\end{array}$ & $\begin{array}{l}\text { See } \\
\text { below }\end{array}$ & 02.06 .1996$. & Consultative & $\begin{array}{l}51.5 \% \\
\text { (average) }\end{array}$ & - \\
\hline 2. & $\begin{array}{l}\text { Ban on the } \\
\text { production of } \\
\text { PVC }\end{array}$ & Kaštela & 14.03 .1999$. & Consultative & $\begin{array}{l}31 \% \\
\text { (insufficient) }\end{array}$ & $89 \%$ for \\
\hline 3. & $\begin{array}{l}\text { Construction } \\
\text { of thermal } \\
\text { power plant }\end{array}$ & Ploče & 25.01 .2015$. & Consultative & $60.4 \%$ & У \\
\hline
\end{tabular}

Sources:

1. SECC - State Electoral Commission of the Republic of Croatia, 1996. Consultative referendums on corrections of the county borders, [online] Available at: http://www.izbori.hr/ws/index.html? docume ntld=DF2CA3FEF99BA5CBC1257C5C004BF6B4 [accessed 1 February 2017].

2. Oršić, Z., 2014. Lokalni referendum u Hrvata. Pollitika.com, [online] Available at: http://pollitika.com/ lokalni-referendumi-u-hrvata [accessed IFebruary2017].

3. Jutarnji list, 2015 a. Ploče - više od $90 \%$ Pločana protiv termoelektrane, [online] 25 January. Available at: http://www.jutarnji.hr/vijesti/hrvatska/ploce-vise-od-90-posto-plocana-protiv-termoelektrane/469261/ [accessed 1 February 2017].

\section{Opening Pandora's Box of initiatives}

Initiatives were introduced into Croatia's political system in the year 2000, when, as part of the constitutional changes brought after the death of Franjo Tuđman, Croatia's first president, the country's semi-presidential political system was transformed into a parliamentary system. According to these changes the Croatian Parliament was obliged to announce an initiative on any topic from its scope of work or of importance for Croatia if this was requested by at least 10 per cent of registered voters (Croatian Constitution, Art. 87; LoR, Art. 3). Just as with the referendums discussed in the previous section, the decisions reached through initiatives are made by a majority of the voters taking part therein and they are binding (Croatian Constitution, Art. 87; LoR, Art. 6 and Art. 8). ${ }^{7}$

6 In Croatia, there is no official data on the exact number of local referendums and initiatives held so far. Therefore, it is possible that the presented data is incomplete. Concerning the referendums under No. 1. these were held in Pag and Novalja district, Zagreb county, Novska, Ivanič Grad, Kloštar Ivanić district, Križ district, Našice, Đurđenovac district, Feričanci district and Podgorač district.

7 Apart from the referendums/initiatives the LOR in Art. 2 recognised meetings and petitions as additional instruments of direct democracy. 
The introduction of initiatives in Croatia has often been criticized as overly simplistic and for not being sufficiently thought-through. Legislators failed to introduce a differentiation between the criteria for initiatives that pursue constitutional changes and those that demand legislative ones (in terms of the number of collected signatures, the length of time for collecting them, etc.). A practice of prohibiting instruments of direct democracy during the last year of the government's mandate as well as within the first six months in office was not accepted. Last but not least, prescribing a time frame of only 15 days for collecting signatures for initiatives was viewed as equally problematic (Pereša and Zelić 2012; Kostadinov 2014; Smerdel 2014; Podolnjak 2014).

The 15-day timeframe for collecting the signatures of about 430.000 citizens at the national level ( $10 \%$ of registered voters) means that without massive organisational capacities on the part of the organizers, national level initiatives have no chance of succeeding. As seen from Table 3, there were more national level initiatives that failed in collecting the required signatures than successful ones. Additionally, the rigorous 15-day timeframe stands in sharp contrast to the undetermined time period that, according to the LoR, the Ministry of Public Administration has for their validation. In practice this means that the government protracts the implementation of initiative if it suits its interests. Defects in the legislative framework regulating initiatives are also visible from the lack of precision in the LoR which allows the government to change the legislation, which is to be voted on, in the period between the initiative's initiation and the actual voting (Periša and Zelić 2012). This opportunity has already been used by the government on three separate occasions (amendments of the Labour Law, outsourcing and monetization of the highways, see Table 3).

Just as for referendums, the implementation of initiatives at the local level is inhibited by the fact that in the post-2010 period, the LoR has not been harmonized with the constitution. For that reason, the success of local level initiatives and referendums depends on the turnout requirement of at least $50 \%$ of the locally registered voters (LoR, Art. 6). As is visible from Table 4, such strict turnout requirements prevent the implementation of most local level initiatives. the LLRS (Art. 24) further specifies that local initiative can be initiated by $20 \%$ of the voters registered in the local or regional unit. 
In the case of recalling the municipal prefect, mayor, county prefect, or their deputies, the LLRS (Art. 40c) notes that the voting is valid if the majority of voters that turned out voted for the recall and if that majority represents at least 1/3 of the total number of locally registered voters. This practically means that a turnout below $50 \%$ has only slim chances for success. Still, in terms of the timing within the recall procedure, the new LLRS goes one step further than the out-dated LoR. Unlike the LoR, which prescribes no limitations on when an initiative can be implemented, the LLRS notes that the recall procedure cannot be carried out within the first 12 months after the local elections took place or within 12 months of the implementation of the previous such recall procedure. Similarly, the recall procedure is prohibited in the last year of the mandate (Art. 40b).

The existing legislation reserves an important place for the Constitutional Court in the implementation of national level initiatives. The Constitutional Law on Implementation of the Constitution of the Republic of Croatia (CLICRC) prescribed that with respect to national level initiatives, the Croatian Parliament can inquire the Constitutional Court about the compatibility between the question posed by the initiative and the Croatian Constitution. In such circumstances, the Court is obliged to provide its answer within 30 days (Art. 95). Local referendums are excluded from the scope of review of the Constitutional Court because of the strict wording of article 95 of the CLICRC, which expressly refers to referendums defined in article 87 (paragraphs 1-3) of the Croatian Constitution. The appropriateness of all questions posed by the local initiatives are examined by the Central Department of State Administration responsible for local and regional self-government. The Central Department also checks the validity of the collected signatures (LLRS, Art. 24). Within 60 days the response regarding the appropriateness and validity of the signatures needs to be delivered (LLRS, Art. 24).

The parliament used the opportunity to inquire the Constitutional Court about the appropriateness of the questions concerning four national level initiatives (amendments to the Labour Law, changing the Constitutional Law on the Rights of National Minorities, outsourcing and monetization of highways, see Table 3), which managed to collect the required number of signatures (CCRC 2010, CCRC 2014a, CCRC 2015a, CCRC 2015b). Regarding amendments to the Labour Law, the Court stated 
that a referendum would be unnecessary because in the meantime the government decided to abandon the proposal. In the remaining three cases the decision of the Court was that the question is unconstitutional (ibid). With respect to the 2013 initiative about the constitutional definition of marriage as a union between one woman and one man, the motion from the Parliament was never sent. Therefore, the Court offered its view through a special document under the title "Statement". In this statement the Court declined to rule that the question was contrary to international and domestic law, which cleared the path for this (and so far the only) successfully implemented national level initiative (CCRC 2013).

The role of the Constitutional Court in regulating the instruments of direct democracy in Croatia is not without controversy. Some scholars have objected to the fact that the current legislative framework allows the Parliament to inquire the Court about the compatibility of national level initiatives with the Constitution but not national referendums. Therefore, it remains unclear, what would be the implications of an activity of the Constitutional Court in the case of national level referendums or initiatives, when the parliament avoids posing a question (Horvat-Vuković 2014; Podolnjak 2014). However, as pointed to by Gardašević (2015), from the point of view of the Constitutional Court itself, this question was resolved in the statement of the Court concerning the constitutional definition of marriage. There the Court revealed its approach to its own review powers, according to which it possesses the general constitutional duty to guarantee respect for the constitution and to supervise the constitutionality of state referendums, until the formal end of the referendum procedure.

The 2010 abolition of the participation quorum at the national level resulted in an increase of initiatives. At the local level, although rules remained unchanged, the frequency of initiatives increased as well, which could be attributed to the general growth of citizens' interest in the instruments of direct democracy.

National level initiatives can easily be divided into two principle groups: initiatives dealing with political issues and initiatives dealing with economic issues. However, there are observable differences between these two groups. While the organizers of initiatives dealing with political issues derive from different groups within civil society (from Christian conservatives and 
war veterans to the pacifist groups) the organizers of the initiatives that focus on the economy are always the trade unions. The later possess organizational capacities that allow them to pursue successful signature collection campaigns. Through their engagement in initiatives aimed at blocking the government's major economic reforms, which otherwise could have obtained majority backing in the Croatian Parliament, the trade unions in Croatia used the instruments of direct democracy to act as veto points on behalf of the status quo.

One differentiation between the initiatives in Croatia and the ones in Hungary, Lithuania and Slovenia is that in Croatia the opposition is not as frequently involved in the implementation of these initiatives, particularly at the national level. This phenomenon could partly be explained with the fact that, unlike in the mentioned countries, in Croatia the oppositional MPs cannot start a referendum initiative. Therefore, the opposition is generally not as familiar with the strategic use of direct democracy. ${ }^{8}$ Additionally, it is not surprising that the initiators of the initiatives that deal with the economy are the trade unions. As the most ardent advocates of leftist ideas in Croatia, the trade unions often claim to have no interlocutors among the political parties, which in their view almost exclusively follow the neoliberal agenda (Butković et al. 2012).

8 The attitudes of the two major political parties (the social democrats and conservatives) towards direct democracy could generally be described as reactive and sceptical. This is best visible from their clear opposition to the initiative that was aimed at introducing preferential voting without census, the lowering of the election threshold and some other changes to the electoral system (see Table 3). In this initiative the leaderships of both major parties recognised the potential danger that their power might be eroded (Vuković 2014). 
Table 3. National level initiatives ${ }^{9}$

\begin{tabular}{|c|c|c|c|c|c|c|}
\hline No. & $\begin{array}{l}\text { TOPIC OF THE } \\
\text { INITIATIVE }\end{array}$ & $\begin{array}{l}\text { INITIATION } \\
\text { OF } \\
\text { INITIATIVE }\end{array}$ & $\begin{array}{l}\text { NUMBER OF } \\
\text { SIGNATURES }\end{array}$ & $\begin{array}{l}\text { TURN } \\
\text { OUT }\end{array}$ & $\begin{array}{l}\text { PERCANTAGES } \\
\text { FOR AND } \\
\text { AGAINST }\end{array}$ & OUTCOME \\
\hline 1. & $\begin{array}{l}\text { Termination of } \\
\text { cooperation } \\
\text { with the } \\
\text { Hague } \\
\text { Tribunal }\end{array}$ & 30.09 .2007 & 296.000 & l & I & $\begin{array}{l}\text { Insufficient } \\
\text { number of } \\
\text { signatures }\end{array}$ \\
\hline 2. & $\begin{array}{l}\text { Croatian } \\
\text { accession to } \\
\text { NATO }\end{array}$ & 29.03.2008. & 126.392 & l & I & $\begin{array}{l}\text { Insufficient } \\
\text { number of } \\
\text { signatures }\end{array}$ \\
\hline 3. & $\begin{array}{l}\text { Arbitration of } \\
\text { the Croatian } \\
\text {-Slovenian } \\
\text { border } \\
\text { delimitation }\end{array}$ & 15.11 .2009 & 200.000 & l & I & $\begin{array}{l}\text { Insufficient } \\
\text { number of } \\
\text { signatures }\end{array}$ \\
\hline
\end{tabular}

1. The initiative on the termination of cooperation with The Hague Tribunal was launched by war veterans who requested a direct vote on the regulation of their status in proceedings concerning the alleged war crimes (Portal hrvatskog kulturnog vijeća 2007).

2. Concerning accession to NATO, an initiative was launched that requested a direct vote on that topic, which has not been envisaged (H-ALTER 2008).

3. The initiative on arbitration of the Croatian-Slovenian border delimitation was targeted against the arbitration agreement which was signed by the two governments. The arbitration was to determine the land border delimitation between the two countries on several micro locations as well as the sea border in the Adriatic Sea. The organizers of this initiative claimed that Croatia needed to pull out of the arbitration agreement. They advocated settling of the border issue at the International Tribunal for the Law of the Sea in Hamburg or at the UN International Court of Justice in The Hague (Večernji list 2009).

4. The trade union confederations started an initiative that would cancel the prolonged application of the expired collective agreements by means of amendments to the Labour Law. The government abandoned this proposal but later these changes were implemented by means of another law (Butković et al. 2012).

5. The initiative also called "Referendum uprising" included the questions on the following issues: a second referendum on the EU membership, the annulment of the privatization process, a ban on GMOs, and a prohibition on the selling of natural resources (Tportal.hr 2013).

6. The constitutional definition of marriage initiative provoked significant debate concerning whether the conservation of cultural concepts such as marriage should have priority over individual autonomy (Gardašević 2015: 10). Furthermore, the initiative provoked polemics on whether constitutional issues should be decided through the initiative process and whether the requirements should remain the same for legislative and constitutional initiatives (Podolnjak 2014). Finally, the Constitutional Court concluded that a decision made by a direct citizens' vote has an immediate transformative effect on the constitutional text (Gardašević 2015: 11).

7. The initiative, which concerned changing the Constitutional Law on the Rights of National Minorities, wanted to harden requirements for the official use of minority languages and scripts in the territories with local selfgovernment. The goal was to prevent the placing of bilingual (Latin and Cyrillic) plates on public buildings in the town of Vukovar, which has a significant Serbian minority. Organizers claimed that Cyrillic scripture in Vukovar is associated with suffering during the war, in which the town was destroyed (CCRC 2014a).

8. After the government announced its plan to outsource all non-core services in the public sector the trade unions started an initiative that would ban outsourcing in the public sector by means of a special law. The Constitutional Court, with respect to this case, argued that direct democracy is permissible and legitimate, but not the primary and ordinary way of deciding on the regulation of economic, legal and political relations (CCRC 2015a).

9. The greatest controversy over the initiative aimed at changing the electoral system was what number constitutes ten per cent of voters in Croatia. The initiative failed because the Constitutional Court took a position that ten per cent should be counted based only on the voters who reside in Croatia (CCRC 2014b).

10. An initiative against the monetization of highways was started by a broad coalition of trade unions and civil society activists who wanted to stop the government's plan to give the motorways, which are public property, to private concessioners (CCRC 2015b).

11. The organizers of this initiative wanted to lower the required number of signatures needed for the initiation of an initiative. Furthermore, they also wanted to prescribe that in all future attempts to regulate direct democracy the signatures for the initiatives must be collected in public places (Jutarnji list 2015b). 


\begin{tabular}{|c|c|c|c|c|c|c|}
\hline No. & $\begin{array}{l}\text { TOPIC OF THE } \\
\text { INITIATIVE }\end{array}$ & $\begin{array}{l}\text { INITIATION } \\
\text { OF } \\
\text { INITIATIVE }\end{array}$ & $\begin{array}{l}\text { NUMBER OF } \\
\text { SIGNATURES }\end{array}$ & $\begin{array}{l}\text { TURN } \\
\text { OUT }\end{array}$ & $\begin{array}{l}\text { PERCANTAGES } \\
\text { FOR AND } \\
\text { AGAINST }\end{array}$ & OUTCOME \\
\hline 4. & $\begin{array}{l}\text { Amendments } \\
\text { to the Labour } \\
\text { Law }\end{array}$ & 09.06.2010. & 717.149 & I & I & $\begin{array}{l}\text { Government } \\
\text { abandoned the } \\
\text { amendments }\end{array}$ \\
\hline 5. & Four questions & 13.02.2013. & $\begin{array}{l}\sim 120.000 \\
\text { per } \\
\text { question }\end{array}$ & I & I & $\begin{array}{l}\text { Insufficient } \\
\text { number of } \\
\text { signatures }\end{array}$ \\
\hline 6. & $\begin{array}{l}\text { Constitutional } \\
\text { definition of } \\
\text { marriage }\end{array}$ & 12.05.2013. & 749.316 & $37.90 \%$ & $\begin{array}{l}65.87 \% \text { for } \\
33.51 \% \text { against } \\
0.62 \% \text { non-valid }\end{array}$ & Successful \\
\hline 7. & $\begin{array}{l}\text { Changing the } \\
\text { constitutional } \\
\text { law on the } \\
\text { rights of } \\
\text { national } \\
\text { minorities }\end{array}$ & 17.11 .2013$. & 632.165 & I & I & $\begin{array}{l}\text { Unconstitutional } \\
\text { question }\end{array}$ \\
\hline 8. & $\begin{array}{l}\text { A ban of } \\
\text { outsourcing }\end{array}$ & 06.06 .2014 & 563.815 & I & I & $\begin{array}{l}\text { Unconstitutional } \\
\text { question }\end{array}$ \\
\hline 9. & $\begin{array}{l}\text { Electoral } \\
\text { system }\end{array}$ & 21.09 .2014 & 386.649 & I & I & $\begin{array}{l}\text { Insufficient } \\
\text { number of } \\
\text { signatures }\end{array}$ \\
\hline 10. & $\begin{array}{l}\text { Against } \\
\text { monetisation } \\
\text { of highways }\end{array}$ & 11.10 .2014$. & 498.545 & I & I & $\begin{array}{l}\text { Unconstitutional } \\
\text { question }\end{array}$ \\
\hline 11. & $\begin{array}{l}\text { Referendum } \\
\text { on } \\
\text { referendum }\end{array}$ & 30.05.2015. & $\begin{array}{l}\text {-340.000 } \\
\text { per } \\
\text { question }\end{array}$ & I & I & $\begin{array}{l}\text { Insufficient } \\
\text { number of } \\
\text { signatures }\end{array}$ \\
\hline
\end{tabular}

Sources:

1. Portal hrvatskog kulturnog vijeća, 2007. 296 tisuća moralnih činova, [online] 18 October. Available at: http://www.hkv.hr/izdvojeno/komentari/mmb/1445-komentar-296-tisua-moralnih-inova.html [accessed 1 February 2017].

2. H-ALTER, 2008. Predaja 126392 potpisa prikupljenih u akciji 'NATO na referendum, [online] 23 June. Available at: http://www.h-alter.org/vijesti/predaja-126-392-potpisa-prikupljenih-u-akciji-nato-nareferendum [accessed 1 February 2017].

3. Večernji list, 2009. Inicijativa More je kopno prikupila oko 200.000 potpisa, [online] 2 December. Available at: http://www.vecernji.hr/hrvatska/inicijativa-more-je-kopno-prikupila-oko-200-tisuca-potpisa-59809 [accessed 1 February 2017].

4. CCRC - Constitutional Court of the Republic of Croatia, 2010. Decision No. U-VIIR-4696/2010, [online] 20 October. Available at: http://narodne-novine.nn.hr/clanci/sluzbeni/2010_10_119_3111.html [accessed 1 February 2017].

5. Tportal.hr., 2013. 'Referendumski ustanak' nije skupio dovoljno potpisa, [online] 22 March. Available at: http://www.tportal.hr/vijesti/hrvatska/250763/Referendumski-ustanak-nije-skupio-dovoljno-potpisa. $\mathrm{html}$ [accessed 1 February 2017].

6. CCRC - Constitutional Court of the Republic of Croatia, 2013. Statement No. SUS-1/2013, [online] 14 November. Available at: http://narodne-novine.nn.hr/clanci/sluzbeni/2013_11_138_2966.html [accessed 1 February 2017].

7. CCRC-Constitutional Court of the Republic of Croatia, 2014a. Decision No. U-VII-4640/2014, [online] 12 August. Available at: http://narodne-novine.nn.hr/clanci/sluzbeni/2014_08_104_2021.html [accessed 1 February 2017]. 
8. CCRC - Constitutional Court of the Republic of Croatia, 2015a. Decision No. U-VIIR-1159/2015, [online] 8 April. Available at: http://www.sdlsn.hr/upload/File/Outsourcing_odluka_Ustavnog_suda_ od_080415_U-VIIR-1159-2015.pdf [accessed I February 2017].

9. CCRC - Constitutional Court of the Republic of Croatia, 2014b. Decision No. U-VIIR-7346/2014, [online] 10 December. Available at: http://narodne-novine.nn.hr/clanci/sluzbeni/2014_12_156_2961.html [accessed 1 February 2017].

10. CCRC - Constitutional Court of the Republic of Croatia, 2015b. Decision No. U-VIIR-1158/2015, [online] 21 April. Available at: http://narodne-novine.nn.hr/clanci/sluzbeni/2015_04_46_919.html [accessed 1 February 2017].

11. Jutarnji list, 2015b. Ipak ništa od referenduma o referendumu, [online] 16 July. Available at: http:// www.jutarnji.hr/vijesti/hrvatska/ipak-nista-od-referenduma-o-referendumu-inicijativa-sindikata-inevladinih-udruga-skupila-premalo-potpisa/281659/ [accessed 1 February 2017].

\section{Table 4. Local level initiatives ${ }^{10}$}

\begin{tabular}{|c|c|c|c|c|c|c|}
\hline No. & $\begin{array}{l}\text { TOPIC OF THE } \\
\text { INITIATIVE }\end{array}$ & TOWN & $\begin{array}{l}\text { DATE OF } \\
\text { VOTING }\end{array}$ & $\begin{array}{l}\text { TURN } \\
\text { OUT }\end{array}$ & $\begin{array}{l}\text { PERCANTAGES } \\
\text { FOR / AGAINST }\end{array}$ & OUTCOME \\
\hline 1. & $\begin{array}{l}\text { Location of the } \\
\text { county's waste } \\
\text { disposal site }\end{array}$ & Viškovo & 04.06.2000. & / & Majority against & $\begin{array}{l}\text { Insufficient } \\
\text { turnout }\end{array}$ \\
\hline 2. & $\begin{array}{l}\text { Separation } \\
\text { from the Lika- } \\
\text { Senj County }\end{array}$ & Senj & 19.01.2003. & $40.4 \%$ & $92.5 \%$ for & $\begin{array}{l}\text { Insufficient } \\
\text { turnout }\end{array}$ \\
\hline 3. & $\begin{array}{l}\text { Separation } \\
\text { from the Blato } \\
\text { municipality }\end{array}$ & Babina & 06.07.2003. & $92 \%$ & $96 \%$ for & Successful \\
\hline 4. & $\begin{array}{l}\text { Recall of the } \\
\text { municipal } \\
\text { prefect }\end{array}$ & Pribislavec & 27.02.2011. & $11 \%$ & $70 \%$ for & $\begin{array}{l}\text { Insufficient } \\
\text { turnout }\end{array}$ \\
\hline 5. & $\begin{array}{l}\text { Recall of the } \\
\text { municipal } \\
\text { prefect }\end{array}$ & $\begin{array}{l}\text { Pučišća na } \\
\text { Braču }\end{array}$ & 06.05.2012. & $31.6 \%$ & $88.7 \%$ for & $\begin{array}{l}\text { Insufficient } \\
\text { turnout }\end{array}$ \\
\hline 6. & $\begin{array}{l}\text { Construction of } \\
\text { accumulation } \\
\text { lake }\end{array}$ & Lokve & 09.06.2013. & $37.8 \%$ & $88.7 \%$ agains $\dagger$ & $\begin{array}{l}\text { Insufficient } \\
\text { turnout }\end{array}$ \\
\hline 7. & $\begin{array}{l}\text { Construction } \\
\text { of wind power } \\
\text { plant }\end{array}$ & Fužine & 14.04.2013. & $46.6 \%$ & $82 \%$ against & $\begin{array}{l}\text { Insufficient } \\
\text { turnout }\end{array}$ \\
\hline 8. & $\begin{array}{l}\text { Golf Park } \\
\text { project on } \\
\text { mount Srđ }\end{array}$ & Dubrovnik & 28.04.2013. & $31.5 \%$ & $84 \%$ against & $\begin{array}{l}\text { Insufficient } \\
\text { turnout }\end{array}$ \\
\hline 9. & $\begin{array}{l}\text { Construction } \\
\text { of composting } \\
\text { plant }\end{array}$ & Goričan & 16.02.2014. & $56.2 \%$ & $97.7 \%$ against & Successful \\
\hline
\end{tabular}

Source: Oršić, Z., 2014. Lokalni referendum u Hrvata. Pollitika.com, [online] Available at: http://pollitika. com/lokalni-referendumi-u-hrvata [accessed 1 February 2017]

10 The initiative, which intended to block the construction of the Golf Park on the mount Sra close to Dubrovnik, was one of the most media exposed local initiatives. The organizers were concerned, among other things, that this project could endanger the regular water supply to the city of Dubrovnik. However, like most of the local initiatives this one also failed to obtain the needed participation quorum (Srđ je naš 2016). 


\section{Towards better regulation of direct democracy in Croatia}

In its October 2010 decision the Constitutional Court noted that the existing legislative arrangements that regulate direct democracy in Croatia lack coherence and need to be changed (CCRC 2010). Specifically, the Court noted that the Croatian Parliament is obliged to harmonize the LoR with the Croatian Constitution and that in doing so the legislator should take into account that the Court on two separate occasions had initiated a review of the LoR's constitutionality. It further noted that provisions of the LoR are insufficiently elaborated, which is visible from the fact that there are no regulations on how to proceed when the government withdraws a proposal that is to be decided upon by means of an initiative. Finally, the Court stressed that provisions of the LoR need to be harmonized with the Code of Good Practice with Respect to Referendums issued by the Venice Commission. ${ }^{11}$

On a number of occasions MPs, experts, and civil society representatives demanded constitutional and legislative changes that would harmonize relations between the constitution and the LOR and make direct democracy more accessible. For example, in June 2010 representatives of the Social Democratic Party of Croatia (then in the opposition) submitted a constitutional amendment aimed at lowering the number of signatures from citizens needed for the initiation of an initiative from 10 to 5 per cent, and forbidding referendums/initiatives concerning human rights, basic freedoms, equality, the rights of the national minorities, as well as taxation and the state budget (Podolnjak 2014: 186). The amendment was not approved, just as the one submitted in October 2012 by 45 MPs, which called for the lowering of the number of signatures to 200.000 (ca. $5 \%$ ) and extending the time for their collection (ibid: 187). Similarly, the NGO GONG recommended lowering the number of signatures to $5 \%$ and extending the period for their collection to two months (Pereša and Zelić 2012). Despite all this, it was not until September 2014 that the government headed by the social democrats proposed the new draft LoR.

The new draft LoR corrects the inconsistency between the Constitution

11 Council of Europe, 2007. Resolution 235. Code of Good Practice on Referendums (adopted by the Council for Democratic Elections and the Venice Commission), [online] 30 May. Available at: https://wcd.coe.int/ViewDoc. jsp? $\mathrm{p}=$ \&id=1133019\&direct=true [accessed 1 February 2017]. 
and the LoR by eliminating the participation quorum at the national level. Still, it keeps the participation quorum at the local level (although somewhat reduced). Transcribing provisions from the LLRS, the draft LoR notes that voting on a local referendum or initiative is valid only if a majority of the voters that voted for the proposal represent at least $1 / 3$ of the total number of the locally registered voters (Art. 21). However, such a still high participation quorum makes the implementation of direct democracy at the local level very difficult.

For the local level initiatives, the strict requirement of conferring signatures from at least $20 \%$ of locally registered voters was relaxed to $15 \%$ for the municipalities of $10.000-100.000$ inhabitants and $10 \%$ for the municipalities of more than 100.000 inhabitants (Art. 9.). Finally, the time frame for the collection of signatures both at the national and at the local level was set at 30 days (Art. 14).

The new draft LoR attempted to abolish the practice of collecting citizens' signatures in public places. Instead it prescribed that signatures should be collected in the offices of the state or local administration (Art. 13) or electronically (Art. 15). However, after numerous protests by representatives of civil society, arguing against this, in their view, undemocratic solution, the government retreated and abandoned this particular provision.

Prior to the publishing of the new draft LoR there was much discussion in Croatia concerning the possible introduction of thematic restrictions to what could be decided by means of direct democracy. In December 2013 the Committee for the Constitution, Standing Orders and Political System of the Croatian Parliament initiated constitutional changes concerning the implementation of direct democracy. Accordingly, referendums and initiatives should not be allowed on issues that address: (i) limitations to human rights and basic freedoms as stipulated by headings II and III of the Croatian Constitution, (ii) obligations deriving from affiliation with international treaties as well as their cancelling, (iii) the state budget and the tax system, (iv) defence and national security, as well as (v) elections and appointments under the jurisdiction of the Croatian Parliament (Croatian Parliament 2013).

Smerdel expressed his reservations concerning this proposal, which soon 
after failed to obtain the needed support in the Parliament (2014: 42). In his view, if implemented, the proposal could create confusion because it avoids clarifying who will decide if some question falls within the ambit of the listed restrictions. Furthermore, he expressed opposition to the wording indicating that referendums would be forbidden on issues concerning human rights and basic freedoms as stipulated in headings II and III of Croatian Constitution. Namely, such a broad formulation, which concerns half of the constitutional text, would make direct democracy literally impossible (ibid). Similar reservations were expressed by Podolnjak, who proposed milder restrictions that would prevent the initiation of referendums and initiatives on matters that are contrary to international law, fundamental principles of democracy, the protection of human rights, basic freedoms, and the rule of law (2014: 211 )..$^{12}$ The author also indicated that initiatives should not be allowed concerning the scope of the constitutional competences of one state body towards another. Finally, Podolnjak noted that the wording of the restrictions is of out-most importance in order to avoid broad interpretations of them, which could make direct democracy impossible (ibid). This is certainly of great importance because some commonly accepted notions - such as for example "state budget" - are so imprecise that their blank insertion on the list of restrictions could present an insuperable obstacle to direct democracy.

Gardašević (2015: 44) and Kostadionov (2014: 132) also argued in favour of narrowing the area of questions that could be decided by means of direct democracy. Furthermore, Gardašević insisted on better regulation of the judicial review process that would cover all cases of referendum decisionmaking and for the language to be more precise concerning procedural rules (2015: 44). Unfortunately, despite this comprehensive debate, the new draft LoR avoided introducing specific thematic restrictions to what could be decided by means of direct democracy. It only introduced a very general restriction indicating that referendums and initiatives cannot decide issues that could endanger the values of the Croatian constitutional order as prescribed by the Croatian Constitution and on issues that are contrary to the supremacy principle of EU law (Art. 3).

According to a proposed draft law the authorities will not be in a position to change decisions reached by referendums or initiatives for a period of

12 In accordance with the Code of Good Practice on Referendums (Council of Europe 2007). 
two years. In the same period, it will not be possible to repeat a particular referendum or initiative (Art. 22). This is an improvement because in the current LoR (Art. 8) these limitations are set at one year concerning changing a decision and at six months concerning repeated voting. Furthermore, it should be underlined that according to the current LoR (Art. 8) a one-year suspension on a possibility to change a decision by representative bodies does not apply to decisions made by popular initiatives and to decisions made by referendums concerning alliances (dissolutions) with other states (see chapter 2). For the NGO GONG the proposed two-year extension is insufficient. They have argued that the initiatives are pointless if the authorities are allowed to alter the decisions reached by them after less than four years (Zelić and Berković 2014) - a view that is shared by the author of this article.

Among most contested aspects of the draft law is the maintenance of the old procedures with respect to the Constitutional Court and the checking of the compatibility between the question posed by the initiative and the Constitution (Art. 18). According to the trade union leader Mijat Stanić, checking the compatibility should have been envisaged in the earlier stages, before and not after the collection of the required number of signatures (Tportal.hr 2015). ${ }^{13}$ Podolnjak has the same view on this matter and he proposed that the organization committee of the initiative first collects 10.000 signatures, after which the Croatian Parliament would be given the opportunity to send an inquiry to the Court. In case the reply from the Court is positive the committee would continue with the collection of signatures (2014: 214).

The draft law was criticized by the NGO GONG for failing to regulate the possibility of an agreement being reached between the organizing committee of an initiative and the authorities. Furthermore, the time frame that the public bodies have at their disposal for checking the validity of the citizens' signatures was not specified, which, just as so far, protracts the process of implementing initiatives (Zelić and Berković 2014). The new draft LoR also failed to introduce different requirements (quorums) for referendums and initiatives which pursue constitutional changes from those that request only legislative ones (Podolnjak 2014:

13 It should, however, be noted that the great majority of national initiatives implemented in Croatia would be dismissed right from the start, without achieving the desired impact on the government, if the constitutionality of these questions was checked before the collection of signatures. 
226). According to Podolnjak, a minimal acceptance quorum of $25 \%$ in case of a legislative referendum or initiative would be beneficial to the Croatian system. It would increase the legitimacy of decisions reached through direct democracy without endangering their implementation (ibid). Finally, the NGO GONG objected that the draft LoR lacks provisions concerning transparent financing of the referendum campaigns as well as signature collecting campaigns. They also indicated that this proposal failed to introduce clear media rules for impartial coverage of campaigns in the area of direct democracy (Zelić and Berković 2014).

In late 2015 the new draft LoR was set to be sent to the Croatian Parliament for a second reading. However, the November 2015 general elections brought a defeat for the ruling socialdemocrats and January 2016 the new centre right coalition government was sworn. That meant that the faith of this latest legislative proposal was sealed. Right from the start the new conservative coalition was burdened with internal conflicts that ultimately ended up leading to a no-confidence vote for the prime minister and the dissolving of the Croatian Parliament in July 2016. The irregular parliamentary elections were held in September 2016, bringing some additional mandates for the main conservative party compared to the previous elections. Therefore, in October 2016 a new conservative coalition government was formed. Judging from the composition of the Croatian Parliament this government has a fair chance to be more stable than the previous one.

\section{Conclusion}

Direct democracy has always been a contested topic. However, today the prevailing dilemma is not whether or not it is beneficial for the overall development of democracy, but rather in what form. In this context, it is crucial to establish a procedural design for direct democracy that contributes to stability without compromising the democratic quality of a given political system. The experiences of Hungary, Lithuania and Slovenia are instructive for Croatia because they show the difficulties in finding the right position and scope for the constructive functioning of direct democracy. In Slovenia, where conditions for the 
implementation of direct democracy are among the most liberal in the world, many initiatives have been held which are arguably not of crucial importance for the country (Kaučič 2014). This is a problem because direct democracy then unnecessarily burdens the state budget and produces polarization in society. On the other hand, imposing a participation quorum of at least $50 \%$, as can be seen in the Lithuanian, the most recent Hungarian, as well as Croatian examples at the local level, blocks the efficient implementation of direct democracy with all of its democratic potential. In Slovenia and Hungary, the past practice of granting the right to start a referendum initiative to a minority group of parliamentarians (the opposition) was singled out as problematic, because it allowed initiatives to be used as a tool for settling differences between political parties (Vospernik 2014: 577; Kaučič 2014: 73). In other words, the initiatives were used for destabilizing the government instead of strengthening democracy from below. Although circumstances differ from country to country, these experiences should be kept in mind when thinking about the future legislative framework for the implementation of direct democracy in Croatia.

In 2010 Croatia lowered the requirements for implementing national level referendums and initiatives in order to secure the passing of the politically important referendum on EU membership. This new situation assured the success of that particular referendum, but at the same time it let the "genie" of direct democracy "out of the bottle". Since 2010 the national level initiatives increased in number and often confronted the government's major reform programmes, which otherwise could have obtained majority backing in the Croatian Parliament. These initiatives, from the perspective of their organizers, could be viewed as successful, despite the fact that only one managed to be implemented in full. Namely, a number of these initiatives were so successful in their capacity to collect a large number of signatures that they persuaded the government to abandon its initial proposals, even before the expected decisions of the Constitutional Court. Therefore, the practical impact of the recently undertaken initiatives in Croatia was that they preserved the status quo and blocked the unpopular but arguably needed reforms. Furthermore, they showed that Croatia, just as the other examined countries, lacks a legislative and institutional framework that supports dialogue and coordination between representative and direct democracy. 
The new draft LoR launched in late 2014 was a long awaited action but in many aspects it has not been properly thought through, leaving numerous problems with respect to the implementation of direct democracy in Croatia unaddressed. It was arguably initially intended to diminish the enlarged power of direct democracy. However, it is questionable whether the general approach chosen by the (former) government in this latest legislative attemptwas the most appropriate. It basically relied on reinforcing the technical requirements for the implementation of initiatives instead of posing thematic limitations to what can or cannot be decided through initiatives. The later approach would be just as, if not more legitimate, and it could be defended with the argument that all issues cannot be decided through direct democracy, which traditionally covers just a small part of legislative decision-making. Still, it should be underlined that with thematic limitations there is always a danger that their broad interpretations might make direct democracy impossible. Therefore, following recent practice in Slovenia, it could be concluded that Croatia needs very precisely defined limitations, particularly concerning terms such as "state budget" which cover vast areas of the government's activities.

For the starting government the adoption of the new LoR represents a task it will certainly need to address, if for no other reason than to correct the current lack of coherence between the implementation of direct democracy at the national and local level. Looking at things from a broader perspective, the process of positioning direct democracy in Croatia as a mechanism for balancing and not always challenging the decisions of its representative democracy will take time. The instruments of direct democracy had not been earnestly introduced into the Croatian political system before the year 2010. Therefore, it is understandable that political actors in the country still search for the most appropriate positioning of direct democracy within the political system. One that allows it to become a tool for improving legislation and facilitating the efficient materialization of bottom-up initiatives, but simultaneously avoids installing it as a veto point on behalf of the status quo. As Croatia continues on this path the experiences of other countries could be valuable, but they cannot replace the learning process that primarily comes from practice. 
Avel, K., and Raunio, T., 2012. Introduction: National Parliaments, Electorates and EU Affairs. In: Auel, K. and Raunio, T., eds. National Parliaments, Electorates and EU Affairs. Vienna: Institute for Advanced Studies, pp. 7-29.

Bernaver, J., and Vatter, A., 2012. Can't get no satisfaction with the Westminster model? Winners, losers and the effects of consensual and direct democratic institutions on satisfaction with democracy. European Journal of Political Research, 51 (4): 435-468.

Boehmke, F. J., and Bowen, D. C., 2010. Direct Democracy and Individual Interest Group Membership. The Journal of Politics, 72: 659-671.

Borner, S., and Rentsch, H., 1997. Wieviel direkte Demokratie verträgt die Schweiz? Chur: Ruegger.

Bowler, S., 2013. When is it ok to limit direct democracy? Minnesota Law Review, 97(5): 1780-1803.

Butković, H., 2015. The Croatian Parliament in the European Union: Ready, Steady, Go! In: Hefftler, C., et al., eds. The Palgrave Handbook of National Parliaments and the European Union. Basingstoke: Palgrave Macmillan, pp. 462-478.

Butković, H., Samardžija, V., and Tišma, S., 2012. The Effects of the Economic Crisis on Industrial Relations in Croatia. Zagreb: Institute for International Relations.

Butler, D., and Ranney, A., 1978. Theory. In: Butler, D., and Ranney, A., eds. Referendums: A Comparative Study of Practice and Theory. Washington: American Enterprise Institute, pp. 23-37.

CCRC - Constitutional Court of the Republic of Croatia, 2010. Decision No. U-VIIR-4696/2010, [online] 20 October. Available at: http:// narodne-novine.nn.hr/clanci/sluzbeni/2010_10_119_3111.html [accessed 1 February 2017].

CCRC - Constitutional Court of the Republic of Croatia, 2013. Statement 
No. SuS-1/2013, [online] 14 November. Available at: http:// narodne-novine.nn.hr/clanci/sluzbeni/2013_11_138_2966.html [accessed 1 February 2017].

CCRC - Constitutional Court of the Republic of Croatia, 2014a. Decision No. U-VII-4640/2014, [online] 12 August. Available at: http:// narodne-novine.nn.hr/clanci/sluzbeni/2014_08_104_2021.html [accessed 1 February 2017].

CCRC - Constitutional Court of the Republic of Croatia, 2014b. Decision No. U-VIIR-7346/2014, [online] 10 December. Available at: http:// narodne-novine.nn.hr/clanci/sluzbeni/2014_12_156_2961.html [accessed 1 February 2017].

CCRC - Constitutional Court of the Republic of Croatia, 2015a. Decision No. U-VIIR-1 159/2015, [online] 8 April. Available at: http://www.sdlsn. $\mathrm{hr} /$ upload/File/Outsourcing_odluka_Ustavnog_suda_od_080415_UVIIR-1159-2015.pdf [accessed 1 February 2017].

CCRC - Constitutional Court of the Republic of Croatia, 2015b. Decision No. U-VIIR-1 158/2015, [online] 21 April. Available at: http://narodne-novine. nn.hr/clanci/sluzbeni/2015_04_46_919.html [accessed 1 February 2017].

CECRL - Central Electoral Commission of the Republic of Lithuania, 2016. Previous Referendums, [online] Available at: http://www.vrk.It/en/ ankstesni [accessed 1 December 2016].

CECRS - Central Electoral Commission of the Republic of Slovenia, 2016. Referendums, [online] Available at: http://www.dvk-rs.si/index. php/si/arhiv-referendumi [accessed 1 December 2016].

CLICRC - Constitutional Law on Implementation of the Constitution of the Republic of Croatia. Zagreb: OG 121/10.

Constitution of the Republic of Croatia. Zagreb: OG 56/90, 135/97, 8/98, 113/00, 124/00, 24/01, 41/01, 55/01, 76/10, 85/10.

Council of Europe, 2007. Resolution 235. Code of Good Practice on Referendums (adopted by the Council for Democratic Elections and the Venice Commission), [online] 30 May. Available at: https:// wcd.coe.int/ViewDoc.jsp? $p=\& i d=1133019$ \& direct=true [accessed 1 February 2017]. 
Croatian Parliament, 2013. Proposal Draft for the Change of the Constitution, [online] Available at: http://www.sabor.hr/prijedlog-nacrtapromjene-ustava-republike-hrvatsk [accessed 1 February 2017].

Fatke, M., and Freitag, M., 2013. Direct democracy: Protest catalyst or protest alternative? Political Behavior, 35(2): 237-260.

Frey, B. S., 2003. Direct democracy for transition countries. Journal of Institutional Innovation, Development and Transition, 7: 42-59.

Gardašević, D., 2015. Constitutional interpretations of direct democracy in Croatia. Iustinianus Primus Law Review, 12(7): 1-46.

Grubiša, D., 2012. Hrvatski referendum za Europsku uniju: anatomija zakašnjelog (ne)uspjeha. Politička misao, 49(2): 45-72.

H-ALTER, 2008. Predaja 126392 potpisa prikupljenih u akciji 'NATO na referendum, [online] 23 June. Available at: http://www.h-alter. org/vijesti/predaja-126-392-potpisa-prikupljenih-u-akciji-nato-nareferendum [accessed 1 February 2017].

Horvat-Vuković, A., 2014. Referendum narodne inicijative 2013. - ustavni identitet kao osnova ustavosudskog aktivizma. In: Podolnjak, R. and Smerdel, B., eds. Referendum narodne inicijative u Hrvatskoj i Sloveniji: Ustavnopravno uređenje, iskustva i perspektive. Zagreb: Hrvatska udruga za ustavno pravo, pp. 149-179.

Hug, S., 2004. Occurrence and policy consequences of referendums: A theoretical model and empirical evidence. Journal of Theoretical Politics, 16: 321-356.

Jung, S., 2001. Die Logik direkter Demokratie. Wiesbaden: Westdeutscher Verlag.

Jutarnji list, 2015a. Ploče - više od 90\% Pločana protiv termoelektrane, [online] 25 January. Available at: http://www.jutarnji.hr/ vijesti/hrvatska/ploce-vise-od-90-posto-plocana-protivtermoelektrane/469261/ [accessed 1 February 2017].

Jutarnji list, 2015b. Ipak ništa od referenduma o referendumu, [online]16 July. Available at: http://www.jutarnji.hr/vijesti/hrvatska/ipak-nistaod-referenduma-o-referendumu-inicijativa-sindikata-i-nevladinihudruga-skupila-premalo-potpisa/281659/ [accessed 1 February 2017]. 
Kaučič, I., 2014. Novo ustavno uređenje zakonodavnog referenduma u Sloveniji. In: Podolnjak, R., and Smerdel, B., eds. Referendum narodne inicijative u Hrvatskoj i Sloveniji: Ustavnopravno uređenje, iskustva i perspektive. Zagreb: Hrvatska udruga za ustavno pravo, pp. 67-89.

Komáromi, L., 2013. Milestones in the history of direct democracy in Hungary. Iustum Aequum Salutare, 9(4): 41-57.

Kost, A., 2008. Direkte Demokratie. Wiesbaden: VS Verlag für Sozialwissenschaften.

Kostadinov, B., 2014. Referendum građanske inicijative. In: Podolnjak, R., and Smerdel, B., eds. Referendum narodne inicijative u Hrvatskoj i Sloveniji: Ustavnopravno uređenje, iskustva i perspektive. Zagreb: Hrvatska udruga za ustavno pravo. pp, 119-149.

Kriesi, H., and Wisler, D., 1996. Social movements and direct democracy. European Journal of Political Research, 30: 19-40.

László, R., 2016. Dismantling direct democracy: Referenda in Hungary, Budapest: Political Capital and Friedrich Ebert Stiftung, [online]. Available at: http://library.fes.de/pdf-files/bueros/budapest/12733. pdf [accessed 1 February 2017].

LEMCP - Law on Election of the Members of Croatian Parliament. Zagreb: OG $116 / 99,109 / 00,53 / 03,69 / 03,167 / 03,44 / 06,19 / 07,20 / 09,145 / 10$, $24 / 11,93 / 11,120 / 11,19 / 15$.

LLRS - Law on the Local and the Regional Self-government. Zagreb: OG 33/01, 60/01, 129/05, 109/07, 125/08, 36/09, 36/09, 150/11, 144/12, $19 / 13,137 / 15$.

LOR - Law on the Referendum. Zagreb: OG 33/96, 92/01, 44/06, 58/06, 69/07, 38/09, 100/16.

Law on the Referendum-draft (LoR draft), 2014. Zagreb, [online] Available at: http://www.sabor.hr/fgs.axd?id=40603 [accessed 30 August 2016].

Lijphart, A., 1999. Patterns of Democracy: Government Forms and Performance in Thirty-Six Countries. New Haven: Yale University Press. 
(2) Lupia, A., and McCubbins, M. D., 1998. The Democratic Dilemma: Can Citizens Learn What They Need to Know? Cambridge: Cambridge University Press.

Machos, C., 2002. Das postsozialistische Parlament in Ungarn - Strukturena und Akteure. In Kraatz, S., and von Steinsdorff, S., eds. Parlamente und Systemtransformation im postsozialistischen Europa. Opladen: Leske und Budrich. pp. 63-85

Maduz, L., 2010. Direct democracy. Living Reviews in Democracy, 2: 1-14. Merkel, W., 2014. Direkte Demokratie: Referenden aus demokratitheoretischer und sozialdemokratischer Sicht. Friedrich Ebert Stiftung. Internationale politikanalyse, [online] March 2014. Available at: http://library.fes.de/pdf-files/id/ipa/10581.pdf [accessed 17 August 2016].

Möckli, S., 1994. Direkte Demokratie: Ein Vergleich der Einrichtungen und Verfahren in der Schweiz und Kalifornien, unter Berücksichigung von Frankreich, Italien, Dänemark, Ireland, Österreich, Lichtenstein und Australien. Bern: Paul Haupt.

National Election Office of Hungary, 2016. National Referendum, [online] Available at: http://valasztas.hu/en/ref2016/index.html [accessed 1 December 2016].

Neidhart, L., 1970. Plebiszit und pluralitäre Demokratie. Eine Analyse der Funktion des schweizerischen Gesetzesreferendums. Bern: Lang.

Oršić, Z., 2014. Lokalni referendum u Hrvata, Pollitika.com, [online] Available at: http://pollitika.com/lokalni-referendumi-u-hrvata [accessed 12 August 2016].

Pállinger, Z. T., 2014. Direct Democracy in Hungary: "A Sad Topic", Democracy International, [online] March. Available at: https:// www.democracy-international.org/direct-democracy-hungarysad-topic [accessed 1 February 2017].

Pereša, I., and Zelić, D., 2012. Analiza referenduma u Hrvatskoj u odnosu na europske standarde. Zagreb: GONG.

Podolnjak, R., 2014. O "ustavnom inženjeringu" referenduma narodne 
inicijative: Neke preporuke hrvatskom ustavotvorcu. In: Podolnjak, R., and Smerdel, B., eds. Referendum narodne inicijative u Hrvatskoj i Sloveniji: Ustavnopravno uređenje, iskustva i perspektive. Zagreb: Hrvatska udruga za ustavno pravo, pp. 178-235.

Podolnjak, R., 2015. Constitutional reforms of the citizen initiated referendum: Causes of different outcomes in Slovenia and Croatia. Journal for Constitutional Theory and Pholosophy of Law, 26: 129-149.

Portal hrvatskog kulturnog vijeća, 2007. 296 tisuća moralnih činova, [online] 18 October. Available at: http://www.hkv.hr/izdvojeno/ komentari/mmb/1445-komentar-296-tisua-moralnih-inova.html [accessed 1 February 2017].

RCIR - Republic Commission for Implementation of Referendums, 1991. Referendum on the Status of Republic of Croatia, [online] 19 May. Available at: http://www.izbori.hr/ws/index.html? documentld=DF2 CA3FEF99BA5CBC1257C5C004BF6B4 [accessed 1 February 2017].

Ribičič, C., 2014. Ustavnopravne granice referendumskog odlučivanja. In: Podolnjak, R. and Smerdel, B., eds. Referendum narodne inicijative u Hrvatskoj i Sloveniji: Ustavnopravno uređenje, iskustva i perspektive. Zagreb: Hrvatska udruga za ustavno pravo. pp, 45-67.

Sartori, G.,1992. Demokratietheorie. Darmstadt: Wissenschaftliche Buchgesellschaft.

Schmitt, B., 2014. Volksentscheid und Volksbegehren: Ein Beitrag zur Auslegung der Weimarer Verfassung und zur Lehre von der unmittelbaren Demokratie. Berlin: Duncker \& Humbolt.

Schumpeter, J. A., 1962. Capitalism, Socialism and Democracy. London: Allen and Unwin.

SECC - State Electoral Commission of the Republic of Croatia, 1996. Consultative Referendums on Corrections of the County Borders, [online] Available at: http://www.izbori.hr/ws/index.html? documentld =DF2CA3FEF99BA5CBC1257C5C004BF6B4 [accessed 1February 2017].

SECC - State Electoral Commission of the Republic of Croatia, 2011. Results of the Parliamentary Elections 2011, [online] Available at: http://www. izbori.hr/izbori/dip_ws.nsf/0/2DF9D413BA2DA73BC125796500586759/\$ 
File/konacni_sluzbeni_rezultati_2011.pdf [accessed 1 February 2017].

SECC - State Electoral Commission of the Republic of Croatia, 2012. Referendum on the EU Membership, [online] Available at: http:// www.izbori.hr/izbori/dip_ws.nsf/public/index? open\&id=9B 1A\& [accessed 1 February 2017].

SECC - State Electoral Commission of the Republic of Croatia, 2015. Results of the Parliamentary Elections 2015, [online] Available at: http:// www.izbori.hr/140zas/rezult/1/nrezultati.html [accessed 1 February $2017]$.

SECC - State Electoral Commission of the Republic of Croatia, 2016. Elections/Referendums Archives in Chronological Order, [online] Available at: http://www.izbori.hr/ws/index.htmle documentld=A7 58299505B80F02C1257C8400606C3B [accessed 1 December 2016].

Smerdel, B., 2013. Ustavno uređenje europske Hrvatske. Zagreb: Narodne novine.

Smerdel, B., 2014. Pregled (tužne) povijesti referenduma građanske inicijative U Hrvatskoj. In: Podolnjak, R. and Smerdel, B., eds. Referendum narodne inicijative u Hrvatskoji Sloveniji: Ustavnopravno uređenje, iskustva i perspektive. Zagreb: Hrvatska udruga za ustavno pravo, pp. 15-45.

Smith, D. A., and Tolbert, C. J., 2004. Educated by Initiative: The Effects of Direct Democracy on Citizens and Political Organizations in the American States. Ann Arbor: The University of Michigan Press.

Somer, E., 2012. Direct Democracy in the Baltic States: Institutions, Procedures and Practice in Estonia, Latvia and Lithuania, C2D Centre for Research on Direct Democracy, University of Zurich, C2D Working Paper Series, [online] March. Available at: http://www. zora.uzh.ch/95339/1/C2D_WP42.pdf [accessed 1 February 2017].

Širinić, D., 2012. Predreferendumska istraživanja i rezultati referenduma. Političke analize, 9: 10-15.

Srđ je naš, 2016., [online] Available at: http://srdjenas.com/srdj2/ [accessed 12 August 2016].

Tportal.hr. 2013. 'Referendumski ustanak' nije skupio dovoljno potpisa. 
[online] 22 March. Available at: http://www.tportal.hr/vijesti/ hrvatska/250763/Referendumski-ustanak-nije-skupio-dovoljnopotpisa.html [accessed 1February 2017].

Tportal.hr., 2015. Okupili se 'referendumaši' i kritizirali Grbinovo rješenje, [online] 17 February. Available at: http://m.tportal.hr/370164/ Okupili-se-referendumasi-i-kritizirali-Grbinovo-rjesenje.html [accessed 1 February 2017].

Vatter, A., 2000. Consensus and direct democracy: Conceptual and empirical linkages. European Journal of Political Research, 38: 171-192.

Večernji list, 2009. Inicijativa More je kopno prikupila oko 200.000 potpisa, [online] 2 December. Available at: http://www.vecernji. hr/hrvatska/inicijativa-more-je-kopno-prikupila-oko-200-tisucapotpisa-59809 [accessed 1 February 2017].

Vospernik, S., 2014. Modelle der direkten Demokratie: Volksabstimmungen im Spannungsfeld von Mehrheits und Konsensdemokratie - Ein Vergliech von 15 Mitgliedsstaaten der Europaishen Union. BadenBaden: Nomos.

Vuković, R., 2014. Nova inicijativa Željke Markić - SDP i HDZ su složni: Ovaj referendum je jako opasan, Jutarnji list, [online] 22 September. Available at: http://www.jutarnji.hr/vijesti/hrvatska/nova-inicijativazeljke-markic-sdp-i-hdz-su-slozni-ovaj-referendum-je-jakoopasan/701509/ [accessed 1 February 2017].

Zelić, D., and Berković, J., 2014. Participation of GONG in internet consultations with the interested public concerning the draft Law on the Referendum. Croatian Parliament, Committee for the Constitution, Standing Orders and Political System, [online] Available at: http://www.gong.hr/hr/izborni-sustav/referendum/ izmedu-ureda-i-trgova-otimanje-slobode-gradanima/ [accessed 1 February 2017]. 
A Hrvoje Butković (hrvoje.butkovic@irmo.hr) is a research associate employed by the Institute for Development and International Relations (IRMO) Zagreb. He defended his PhD on the topic of the EU's democratic deficit in 2010 at the Faculty of Political Science of the University of Zagreb. He published scientific and professional articles addressing democracy in the EU, EU enlargement in South-Eastern Europe and industrial relations in Europe. He also participated in the implementation of international research projects focusing on the various aspects of Croatia's integration in the EU and on development of industrial relations in the EU. 